\title{
Dijimodern Çağda Yalnızlaşan Birey Eleştirisi: Lipton Reklam Filmi Üzerine Bir İnceleme
}

Fikret Yazıcı (Dr. Öğr. Üyesi)

Erciyes Üniversitesi Illetişim Fakültesi

fyazici@erciyes.edu.tr

Orcid: 0000-0003-1821-0973

Başvuru Tarihi: 31.05.2019

Yayına Kabul Tarihi: 02.07.2019

Yayınlanma Tarihi: 22.07.2019

DOI: $10.17680 /$ erciyesiletisim.572321

Yazıcı, F. (2019). Dijimodern Çağda Yalnızlaşan Birey Eleştirisi: Lipton Reklam Filmi Üzerine Bir İnceleme. Erciyes İletişim Dergisi, 6 (2), 863-880. DOI: 10.17680/erciyesiletisim.572321

\section{Öz}

İnternetin toplum yaşamına girmesiyle beraber hızla değișen ekonomik, kültürel ve sosyal yaşam beraberinde teknoloji ve dijitalleşme odaklı yeni bir paradigma oluşturmuştur. Bu bağlamda, cep telefonları, tabletler ve bilgisayarlar başta olmak üzere birçok elektronik cihaz, sanal tatminler sağlayarak bireylerin yüzyüze iletişim alışkanlıklarını kökten değisstirmiştir. Sosyal medya ortamlarında sanal cemaatler üzerinden sosyalleşen bireyler; ev, işyeri ve sosyal yaşam alanlarında izole edilmiş, duyarsız ve yalnızlaşmıştır. Medya içerikleri bireylerin gündelik yaşam pratiklerini belirlemede son derece etkili imgeler sunmaktadır. Özellikle reklamların anlatı dilini daha etkili ve güçlü hale getirmek için görsel/işitsel imgeler yoğun bir şekilde kullanılmaktadır. Reklam filmleri oluşturdukları görsel/işitsel dil sayesinde sadece ürünü satmayı amaçlamamaktadır. Aynı zamanda toplum yaşamını yeniden şekillendiren amaçlı bir ideoloji, kültür ve siyasa da oluşturmaktadır. Çalışmada, dijimodern çağın yalnızlaştırdığı bireylerin geleneksel değerlere nasıl yabancılaştı̆̆ı "Konuşalım Artık" temalı Lipton reklam film üzerinden incelenmiștir. Film, göstergebilimsel analiz yöntemi esas alınarak çözümlenmiștir. Gösteren-gösterilen ilişkisinin ele alındığı çözümleme sürecinde, içeriklerin düzanlam/yananlam düzleminde oluşturduğu anlamsal yapı açılanmaya çalışılmıştır. Bireyin yalnızlaşmasında teknoloji ve dijitalleşme etkisi araştırılmıştır.

Anahtar Kelimeler: Dijimodern Çağ, Reklam, Yalnızlık. 


\title{
Criticism on the Isolated Individual In Digimodern Era: An Analysis on Lipton Television Advertising
}

\author{
Fikret Yazıcı (Asst. Prof. Dr.) \\ Erciyes University Faculty of Communication \\ fyazici@erciyes.edu.tr \\ Orcid: 0000-0003-1821-0973
}

Date Received: 31.05.2019

Date Accepted: 02.07.2019

Date Published: 22.07.2019

DOI: $10.17680 /$ erciyesiletisim.572321

\begin{abstract}
With the introduction of the Internet into the social life, the rapidly changing economic, cultural and social life have created a new paradigm with focus on technology and digitalization. In this context, many electronic devices, especially smart phones, tablets and computers, have changed the face- to- face communication habits of individuals by providing virtual satisfaction. Individuals socializing through virtual communities in social media environments have become isolated, insensitive and lonely in home, workplace and social life areas. Media contents provide highly effective images in determining the daily life practices of individuals. Especially visual/audio images are used intensively to make the narrative language of advertising more effective and powerful. TV advertising films are not intended only to sell the product thanks to the visual/audio language they create. At the same time, it creates an ideology, culture and policy aiming at reshaping community life. In this study, the alienation process of the digimodern era individual to the traditional values is examined through the TV advertising film from Lipton themed "Let's Talk Now". The film was analyzed in line with the basis of semiotic analysis method. In the process of analyzing the relationship between the presenter and the presented, the semantic structure created in the denotation/connotation plane is aimed to be explained. The effect of technology and digitalization was investigated in the isolation of the individual.
\end{abstract}

Keywords: Digimodern Age, Advertising, Loneliness. 


\section{Giriş}

Bilgi ve iletişim alanındaki gelişmeler ve İnternet'in toplum yaşamına girmesiyle beraber çok hızlı bir dönüşüm yaşanmıştır. Günümüz toplum yaşamı özellikle 2000'li yılların başlarından itibaren (Facebook: 2004, Twitter: 2006) hızl bir dijital sosyalleșme sürecine girmiștir. Sosyal ağların sunduğu sanal ortamlar ile toplumsal mekanlar anlamsızlaşmış ve iletişim daha çok web ortamlı, zamanın ve mekanın sınırlandırılmadığı siberalem formuna dönüşmüştür. Özellikle genç kuşak bireyler yeni iletişim teknolojilerini sosyal ağ ilişskileri kurmada aktif olarak kullanmaktadırlar.

Z kuşağı olarak adlandırılan 2000 ve sonrasında doğmuş kişiler kendinden daha önceki Xve Y kuşağına oranla bireycilikleri daha yüksek olarak değerlendirilmektedir. $\mathrm{Bu}$ durumun $\mathrm{Z}$ kuşağının içine doğduğu dünyanın fiziksel şartlarıyla doğrudan ilişkili olduğunu söylemek mümkündür. Erken yaşta eğitim alan, bilgiye ulaşma kapasiteleri teknoloji sayesinde çok daha yüksek olan, sosyal medya mecralarını etkin kullanan bu bireyler dijital çağın çocukları olarak adlandırılmaktadır. Oyuncak yerine akıllı telefonlar, tabletler ve bilgisayarları kullanan bu nesil sosyalleşme aracı olarak daha çok interneti tercih etmektedirler (Taş ve ark., 2017, 1036). Dijital yerliler olarak da bilinen bu kuşak yaşamı, ağ tabanlı bir görsellik perspektifinde algılamakta ve bireysel etkinliği merkeze alan bir paradigma (Prensky, 2001) ile yaşamı yorumlamaktadırlar.

Dijitalleşme sadece birey odaklı yaşam formunu ortaya çlkarmamıştır. Modern insanı dönüştürmüş ve gündelik yaşam pratiklerini doğrudan etkilemiştir. Yeni iletişim teknolojileri sadece bilgi teknolojisi olmaktan fazlasını ifade etmektedir. $\mathrm{Bu}$ teknolojiler eğlence, iletişim, multimedya, bilgi ve eğitimin önemli unsurlarını içermekte, böylece bireylerin hem çalışma hayatını hem de boş zaman uğraşlarını kuşatmakta ve yeniden yapılandırmaktadır. Mevcut kültürün eski bilinen formları, internet tarafından çok seri bir şekilde işgal edilmektedir. Temel işlevi eğlence, eğitim, oyun ve iletişim kaynağı olan bilgisayar, tablet, cep telefonu; sadece dış dünyayla bağlantıyı sağlamakla kalmayıp evlerin demirbaş eşyaları haline dönüşmüşlerdir (Kellner, 2010, 41).

Teknolojik gelişmeler insan doğasını köklü değişimlere uğratmaktadır. Hızla değişen dünya kültürlerarası yeni yaşam formlarını bireylere zorlamaktadır. Dijimodern çağ olarak adlandırılan bu dönem "kültürel bir değişim" olarak adlandırılmaktadır (Kirby, 2009, 50). Postmodern dönemin devamı olarak adlandırılan dijimodern çağ tam anlamıyla postmodernizmden bir kopuşu içermemektedir. Özellikle elektronik araçların insan yaşamına girmesi yeni bir paradigmayı da beraberinde getirmiştir. Postmodernizmin getirdiği bireycilik; içinde yaşadığı çevreyi kontrol eden, şekillendiren, düzenlenmiş ve sıradan olanı bırakıp farklılıkları yaşayan, denemeyi arzulayan, sürekli değișen arzulara sahip olan (Odabaşı, 2012, 60) bir özne kalıbı ortaya çıkarmıştır. Dijimodern çağ postmodernizmin ortaya çıkardı̆̆ı bu bireyselliği teknolojik olarak dönüştürmüş ve tartışmalı hale getirmiștir. Dijital yaşamın ayrılmaz parçaları olan elektronik cihazlar bireyi sosyal çevresinden uzaklaştırmakta ve izole bir dünyada yaşamasına neden olmaktadır. Yüzyüze ilişkileri zayıflayan bireyler bir taraftan yalnızlașırken diğer taraftan internet ve teknoloji sayesinde sosyal ağlara sürüklenmektedir (Vermeulen ve Akker, 2010). $\mathrm{Bu}$ ikilem insan ilişkilerinin boyut değiștirdiğini ve bu değişimde dijitalleșmenin yadsınamaz rolü olduğunu göstermektedir. 
Teknolojinin yalnızlaştırdığı birey eleştirisi birçok medya içeriğinde yer bulmakla beraber, reklam metinlerinde de sıklıkla kullanılmaktadır. Geleneksel değerlerin elektronik araçlar vasıtasıyla yıpratılması reklam filmlerinde içerik olarak dönem dönem işlenmektedir. Örneğin Sütaş, Ramazan Bayramı için hazırladığı özel reklam filminde yaşlılık, yalnızlık ve geleneksel değerler bağlamında mobil teknoloji eleştirisi yapmıştır. Bayramın birinci gününde evinde çocuklarını bekleyen yaşlı anne; oğulları, gelinleri ve torunları geldiğinde cep telefonlarını toplayarak kaldırır ve bayram sofrasına geçilir. Bu sayede aile bireyleri kaynaşır ve mutlu bir bayram günü geçirilir(https://www.youtube.com/watch?v=X51qzrJ60Gc). Yine Coca Cola'nın "Sosyal Medya” temalı hazırladığı reklam filmi de benzer bir eleştiriyi çarpıcı bir şekilde ortaya koymaktadır. Filmde akıllı telefonlar aracılığı ile sosyal medya platformlarında gezen insanların dış dünyadan uzaklaşmaları ele alınmaktadır. Coca Cola bir "sosyal medya koruyucusu" hazırlar ve insanlar bunları boyunlarına takarlar. Böylece akıllı telefon ve tabletlerinden kurtulan insanlar tekrar gerçek sosyal çevresine yönelir(https://www.youtube.com/watch?v=RiUNAjaeAFc).

Bu bağlamda, çalışma son yıllarda hızla artan dijitalleşmenin ortaya çıkardığı "sosyal yalnızlık" temasını eleştirmektedir. Elektronik cihazlar, sanal iletişim ve sosyal ağlar bireyin yalnızlaşmasını sağlarken aynı zamanda geleneksel birçok değerin de yok olmasına sebep olmaktadır. Çalışmada Lipton'un hazırladığı ve "yalnızlaşan birey" eleștirisini sunduğu reklam filmi dijimodern toplum ilişkileri bağlamında göstergebilimsel açıdan analiz edilmiştir.

\section{Postmodern'den Dijimodern'e Evrilen Toplumsal Yaşam Dinamikleri}

1990'ların ortalarından itibaren internetin toplum yaşamına girmesi önemli toplumsal değișimleri de beraberinde getirmiștir. Postmodern söylem kültürel, teknolojik ve siyasal olarak dönemi ifade etmekte ve açıklamakta yetersiz kalmıştır. Çağın yetkin teknolojik gelişmesi olarak internet yeni bir kültürel paradigmayı ortaya koymuş ve "Dijimodernizm" anlayışı ortaya çıkmıştır. Postmodernizm, Aydınlanma düşüncesi sonrası ortaya çıkan bir düşünce ve toplumsal dönüşüm akımı olarak adlandırılmaktadır. Düşünsel olarak postmodernizmi modernizme karşı bir sorgulama ve eleştiri geliștirme süreci olarak açıklamak da mümkündür (Möngü, 2013, 28). Postmodern dönemde bilimsel bilginin modernite sürecinde sarsılan otoritesinin yerini anlatı çokluğu ve yöntem özgürlüğünün alması söz konusudur. Bu paradigmadan değerlendirildiğinde karşıtlıklar, çelişkiler, hiyerarşi ve ilerlemeden bahsetmek mümkün değildir. Onun yerine indirgenemez farklılık, olumsallık, tercihler, eş değerlik ve ortak ölçülemezlik durumu vardır. Yani modernitedeki geçerli ölçütler değişime uğramıştır. Özünde postmodernin, modernin içerisinde sunulamayanın peşinde olduğunu söylemek mümkündür (Lyotard, 1994, 64).

Postmodern kültür anlamların tüketildiği ve kimlik inşasında bu anlamların önemli rol aldığı bir yaklaşımı egemen kılmıștır. Bu anlamlar bireylerin sosyal konumlarındaki davranış biçimlerine göre oluşturulmaktadır. Nesneler ve eylemlerin anlamları göstergeler sisteminden soyutlanmış basit bir şekilde yapılandırılmamıştır. Bir kültürel nesnenin veya hareketin anlamlarının daima metinlerarasılık süreciyle oluşturulması ve kurgulanması süreçleri söz konusudur. Bu yapıyı oluşturma aşamasında, imgeler, metaforlar ve anlatı yolu ile zaman içinde biriktirilen kültürel her türlü kaynak kullanılmaktadır. Anlamlar çoğu zaman sonsuz bir şekilde gönderme yapan sembolik söylemler olarak tasarlanmıştır. Nesnelerin 
ve hareketlerin anlamları hiçbir zaman tek ve soyutlanmış bir göstergebilimsel sistem içinde tasarlanmamıştır (Holt, 1997, 329). Dijimodern olarak adlandırılan içinde yaşadığımız dönem ise, postmodernizmden bu noktada ayrılmaktadır. Dijimodern çağda metinselliğin ve kültürün dijitalleşmenin yayılması ile değişime uğradığını ve yeniden tanımlanması gerektiğini söylemek mümkündür. Dijimodern yaklaşımda metin, okuyucuyu eş zamanlı olarak yakalamak istemektedir. Metinde zamanın başlangıcı vardır ancak sonu belli değildir. Bu sonsuzluk metnin zaman içerisinde nasıl bir gelişim göstereceğine dair bir belirsizlik yaratmaktadır. Metnin içeriğine dair sonsuz sayıda ihtimal belirmektedir. Dijimodern metinlerde yazarlık çokludur ve sözde sosyal topluluklar arasında dağılmış bir şekilde yer almaktadır (Kirby, 2009, 52 -53).

Kültürel metinlerin form ve içerik olarak değiștiği bu çağda, bireylerin de dönüşüme uğradığını söylemek mümkündür. Dijital kültür, içinde varolan dijital teknoloji ve bu teknolojiyi kullanan dijital bireyler aracılığı ile oluşturulmuştur. İnternet'in toplum yaşamına girmesiyle beraber yeni bir nesil de ortaya çıkmıștır. Hayatları bilgisayar oyunları, elektronik posta ve dijital haberleşme, internet, cep telefonları, tabletler, sosyal ağlar ve anlık mesajlaşma uygulamaları olan bu nesil; önceleri $\mathrm{N}$ jenerasyonu (Net Jenerasyonu) daha sonra D jenerasyonu (Dijital Jenerasyon) gibi tanımlamalarla açıklansa da günümüzde "Dijital Yerliler" (DigitalNatives) olarak adlandırılmaktadır (Prensky, 2001, 1). Dijital yerliler, yaşamlarının önemli bir bölümünü ağ ortamlarında geçirmektedirler. Bu durum beraberinde bir kimlik karmaşasını da beraberinde getirmektedir. Bireylerin "çevrimiçi" ve "çevrimdışı" olmak üzere ayrı iki farklı sanal kimliği ortaya çıkmaktadır. Dijital çağda yaşayan ve teknolojiyi kullanan herkes benliğin gerçek anlamda ve çevrim içindeki ifadesinin bir sentezi haline gelmektedir. Birey giderek sadece kendisi hakkında söyledikleriyle ve gerçek yaşamda yaptıkları ile değil, aynı zamanda arkadaşlarının söyledikleri ve yaptıklarıyla da șekillenen bir sosyal kimliğe bürünmektedir (Palfrey ve Gasser, 2017, 31-32). Dijimodernizmin açıklamaya çalıştığı da tam olarak bu değișen ve kompleks hale gelen kimlik algısıdır.

Bireylerin özellikle sosyal paylaşım ağları aracılığı ile kurdukları iletişimin doğasını anlamak bu noktada önem kazanmaktadır. Kullanıcılar, ihtiyaçlarını karşılayan ve sonunda kendilerine tatmin sağlayan bir mecra olarak sosyal ağlara yönelmektedirler (Torlak ve Ay, 2014, 85). Kullanımlar ve Doyumlar teorisi bağlamında değerlendirildiğinde sosyal ağlara yönelik ilginin çeşitli sebepleri ortaya çıkmaktadır. Sosyal etkileşim, bilgi arayışı, zaman geçirme, eğlence, rahatlama, iletişimsel fayda, kullanım kolaylığı, fikirleri ifade etme, bilgi paylaşımı ve başkalarını gözetleme/başkaları hakkında bilgi sahibi olma olmak üzere 10 farklı kullanım ve tatmin alanı (Whiting ve Williams, 2013) kullanıcıları sosyal iletişim ağlarına yönlendiren unsurlar olarak dikkat çekmektedir. Bu yönlendirme aynı zamanda bu mecralara yönelik bağımlılığı da beraberinde getirmekte ve bireyleri yalıtılmış sanal ortamlara hapsetmektedir. Günümüzde özellikle $\mathrm{Z}$ nesli üzerinden bireylerin sosyal medya bağımlısı olduklarını söylemek mümkündür. Geleneksel medya araçları üzerine kurgulanan gönderici-alıcı ilişkisi, dijimodern dünyada yerini içeriğe bağımlı ve medya ile izleyici arasında simetrik olmayan daha karmaşık bir sürece bırakmıştır (Ayhan ve Çavuş, 2014, 54-55). Bu süreci iletişim akışının düz çizgisellikten hipermetinselliğe evrilmesi (Babacan, 2015, 37) olarak adlandırmak da mümkündür. 


\section{Dijimodernizm ve Reklam}

Bireycilik postmodern dönemin en belirgin özelliklerinden biri olarak açıklanmaktadır. Postmodern birey kendi farklılıklarını ortaya koymak için son derece isteklidir. Bu isteklerini toplumda yaşayan diğer bireylerden farklı bir biçimde ifade etme ve satın alma eylemlerini de bireycilik paradigmasıyla gerçekleştirmektedir. Yaşanılan bu çelişki ve tutarsızlıkları postmodern tüketicinin ne istediğini bilmemesi ile açıklamak mümkündür. Herhangi bir yerde ve zamanda bir ürünü görmesi, ona ihtiyacının olduğunun farkına varması için yeterlidir. Bu durum, tüketicilerin ne istediğini kavrayıp bu isteklere uygun yer, zaman ve planla geri bildirimde bulunduğu eski pazarlama düşüncesinden çok daha farklıdır. Postmodern tüketiciler "ne istediğini bilmediği" halde "ne istediğini biliyormuş" gibi görünen bireyler bütünü olarak görülmektedir. Sermaye yapıları ürün pazarlama sürecinde ve buna uygun iletişim stratejilerini geliştirirlerken bireylerin ne istemediklerini keşfetmek ve onların yerine yeni seçenekler sunmak için çaba göstermektedirler (Proctor ve Kitchen, 2002, 144-154). Bilgisayar ve mobil iletişim teknolojilerinin bütünleşmesi ve beraberinde pazarlama adına zaman ve mekan sınırlarını kaldırmıştır. Dijimodern çağda artık seçenek çoktur. Tüketiciye hangi araçla ulaşmalıyız sorunsalı yerini nasıl bir içerikle iletişim kurmalıyız yaklaşımına bırakmıştır.

Yeni teknolojiler sadece bilgi teknolojisi olmaktan çok daha fazlasını ifade etmektedir. Bu teknolojiler eğlence, multimedya, bilgi, iletişim ve eğitimin önemli unsurlarını içinde barındırmakta, böylece bireylerin hem çalışma hayatını hem de boş zaman aralıklarını kuşatmaktadır. Bu kuşatma beraberinde gündelik yaşam ve tüketim pratiklerini de yeniden yapılandırmaktadır. Postmodern kültürün eski bilinen formları internet tarafından çok hızlı bir şekilde işgal edilmektedir. Temel işlevi eğlence, eğitim, oyun ve iletişim olan bilgisayar, artık sadece dış dünyayla bağlantıyı sağlamakla kalmayıp evin ve gündelik yaşamın mobilize olan en önemli dinamiklerinden birine dönüşmüştür (Kellner, 2010, 41).

McLuhan (1964, 32), kitle iletişim araçları içerisinde televizyonun çok önemli bir yeri olduğunu söylemektedir. Ona göre televizyon kültürel içerikli konularla değil, tekniği ve yapısıyla açıklanması gereken bir sosyal yaşam bileşenidir. "Araç mesajdır" yaklaşımıyla teknolojik medya biçimlerinin insan algısını nasıl şekillendirdiği üzerine bir gönderme yapmaktadır. Baudrillard (2012) ise bu yaklaşımı destekler ve bir adım öteye taşıyarak televizyonun medya kültürünün merkezi bir parçası olduğunu dile getirir. Artık televizyon, ev içinde dünyayı kolayca tüketilebilir toplumsal gerçeklik parçalarına çeviren derinliksiz, yapay bir ilişki sunmaktadır. Dijimodern çağ ise teknoloji marifetiyle televizyon dahil olmak üzere kitle iletişim araçlarının tamamında bir dönüşüm gerçekleştirmiş ve tüketim alışkanlıklarını değiștirmiştir. Televizyon artık sadece tüketmeyi öğreten bir aracı düzleminden ayrılmıș, tüketimi birlikte yaşatan interaktif teknoloji donanımlarıyla dizayn edilmiștir. Reklamcılık endüstrisi bu hızlı değișimin gerisinde kalmayarak yeni reklam içeriklerini ve stratejilerini dijimodern çağ multimedya içeriklerine uyarlamıştır. Advertorial reklamlar, ürün yerleştirme, sanal reklam uygulamaları olmak üzere birçok yeni strateji; dizi, sinema filmi, yarışma, spor programları başta olmak üzere birçok programa entegre edilmiştir. Ortaya çıkan bu yeni reklam anlayışı tüketim alışkanlıklarını da derinden etkilemiştir. 
Dijimodern dünyada tüketim kültürünü oluşturan reklamcllık endüstrisinin, küresel sermaye ile uyumlu bir "dünya tüketicisi" oluşturması söz konusudur. Bu yeni paradigma "standartlaștırılmış küresel bir kültür" ortaya çıkarmaktadır. Bu kültürün oluşturulması ise simgelere dayalı bir toplumsal anlayışın kazanılması ile gerçekleşebilir görülmektedir. Reklamcılık endüstrisi, artık ürünün sunumunu yapan faaliyet esaslı bir yaklaşım yerine, ürünün algılanışını materyal ve mental olarak kurgulayan endüstriyel bir yaklaşıma evrilmektedir (Tellan, 2008, 47). Toplumsal imaj kültürünü derinden etkileyen bu durum için "teknolojik devrim" tanımlaması yapılmaktadır. Çok hızlı bir şekilde ilerleyen bu süreç imajları üretenler ve tüketenler için devrimci bir anlam içermektedir. Yeni elektronik teknolojiler imaj yaratmada adeta sınırsız bir özgürlük ve esneklik ortaya koymaktadır. Bu yaşanılanlar yeni bir çağın başlangıcı olarak değerlendirilebilir (Robins, 1999, 238239). Dijimodern teknoloji bütünüyle yeni bir görsel söylem oluşturmaktadır.

\section{Amaç ve Yöntem}

Araştırmanın temel amacı, dijimodern çağda bireyin yalnızlaşmasını ele alan Lipton (Konuşalım Artık temalı) reklam filminin göstergebilimsel olarak çözümlemesini yapmaktır. Çalışmada görüntü düzleminin çözümlenmesi, dilsel ileti düzleminin çözümlenmesi ve reklam filminde işlenen teknoloji odaklı yalnızlık temasının düz anlam/yan anlam düzleminde göstergebilimsel olarak çözümlenmesi aşamaları gerçekleştirilmiştir. Araştırmanın göstergebilimsel olarak elde edilen verileri betimsel olarak analiz edilmiştir. Betimsel analiz yaklaşımı, daha önceden belirlenen temalara göre özetleme ve ortaya çıkan verileri yorumlama içermektedir (Yıldırım ve Şimşek, 2008, 224). Bu bağlamda, 2018 yılı Ocak ayında hazırlanan 60 saniye ve 28 plandan oluşan "Konuşalım Artık" temalı Lipton reklam filmi örneklem olarak alınmıştır.

Göstergebilim, göstergelerin ve onların çalışma biçimlerinin araştırılmasına dayanan bir bilim dalıdır. Göstergebilime göre; göstergenin kendisi, içinde göstergelerin düzenlendiği kodlar ya da sistemler ve kodlar ve göstergelerin içinde işlediği kültür çalışma alanı olarak değerlendirilmektedir (Fiske,2015, 122). Gösterge, duyularımızla alımlayabildiğimiz, kendisinden başka bir șeye gönderme yapan fiziksel bir nesne ya da varlık (Barthes, 1979, 26) olarak tanımlanırken; gösterilen, göstergenin anlamlandırma süreci sonucunda bireyin zihninde oluşan görüntü (Fiske, 2015, 123) olarak açıklanmaktadır. Gösteren ise, gösterilenin gerçek dünyadaki görülür formu (Küçükerdoğan, 2011, 173) olarak ifade edilmektedir. Süreç içerisinde, gösterenler düzlemi anlatımlar düzlemini oluştururken, gösterilenler düzlemiyse içerik düzlemini oluşturmaktadır (Barthes, 2005, 47).

Medya içeriklerini incelemenin en temel yolu onu "metin" olarak ele almaktan geçmektedir. $\mathrm{Bu}$ bakış açısıyla romanları, televizyon programlarını, filmleri ve reklamları iletişimin yazılı biçimleri kadar birer metin olarak değerlendirmek gerekmektedir. Bu metinlerin içerisine yüklenen anlamlar son derece önemlidir. İleti ve anlamlar hem açık (apaçık ve ortada) hem de kapalı (az yada çok gizlenmiş ve ima edilen) olarak kodlanmaktadır (Burton, 1995, 38-38). Her anlatı; başlangıç durumu, dönüştürücü öğe, eylemler dizisi, dengeleyici/düzenleyici öğe ve bitiş durumu olmak üzere beş evre içermektedir. Bu bağlamda, anlatısal metin kendi içinde mantıksal ve zamansal bir ilişkiyle eklemlenen gerçek ya da düşsel bir olaylar dizisi üzerine kurgulanmaktadır (Kıran ve Kıran, 2003, 21-22). Her anlatısal metin, içinde barındırdığı göstergeleri kullanan bireyin kültürel ve kişisel deneyimiyle etkileşim 
içindedir. Bu müzakereli ve etkileşimci anlam düşüncesinin çözümlenebilmesi için iki farklı düzeyi incelemek gerekmektedir (Fiske, 2015, 181). Bunlar; düz anlam ve yan anlam düzeyleridir.

Medya metinlerini göstergebilimsel olarak okuma sürecinde her anlatım türü için düz anlam ve yan anlamdan bahsetmek gerekmektedir. Düz anlam anlamlandırma sürecinin birinci düzeyidir. Bu düzeyde, göstergenin göstereni ve gösterileni arasındaki ilişki ve göstergenin dişsal gerçeklikteki göndergesiyle ilişkisi betimlenmektedir (Fiske, 2015, 181). Bir göstergenin sadece düz anlam taşıdığını söylemek mümkün değildir. Çağrışımsal anlam olarak da adlandırılan yan anlam; göstergenin kullanıcıların duygularıyla ya da heyecanları ve kültürel değerleriyle ortaya çıkan etkileşimini açıklamaya çalışmaktadır (Ünal, 2014, 26). Yan anlamlara yönelik çağrışımları düz anlam gerçekleştirmektedir.

Reklamlar, doğası gereği satın alma faaliyetini oluşturan ve örgütleyen dinamik yapıya sahip bir süreçtir. Sadece satmaya çalıştıkları ürünlerin içinde var olan nitelik ve özellikleri değil, bu malların insanlar için bir şeyler ifade eder hale gelebildiği biçimi de dikkate alarak dizayn edilmektedirler (Williamson, 2001, 12). Her reklam filmi belli bir anlatı, bir öykü, bir ileti aktarmak üzerine kuruludur (Küçükerdoğan, 2011, 180). Dolayısıyla gösteren-gösterilen ilişkisi birbirini tamamlayan iki önemli düzlem olarak incelenmelidir. Çalışmada temel olarak; "dijimodern çağ bireyi yalnızlaştırmakta mıdır?" sorusu sorulmuştur. Bunun yanı sıra çalışmada dijimodern yaşam pratikleri arka planında Lipton'un hazırladığı "Konuşalım Artık" temalı reklam filmi; reklamda yer alan ve doğrudan algılanabilen gösterenler (düz anlam) ve anlamın içeriğini oluşturan gösterilenler boyutu(yan anlam) ile çözümlenmeye çalışılmıştır. Bu bağlamda çalışmanın alt soruları şunlardır:

- Dijitalleşme ve yalnızlık arasında nasıl bir ilişki vardır?

- Dijimodern çağ geleneksel kültürel değerleri değiştirmiş midir?

\section{Bulgular}

\section{Lipton "Konuşalım Artık" temalı reklam filmi:}

2018 yılının Ocak ayında yayınlanan Lipton reklam filmi "Konuşalım Artık " etiketini taşımaktadır. Reklam filmi 60 saniye sürmekte ve 28 plandan oluşmaktadır. Film teknoloji ve gündelik yaşam eleștirisi yapmakta ve kaybolan geleneksel değerlere dikkat çekmektedir. İnsanların birbirlerine karşı duyarsızlığı, ilişkilerin zayıflaması ve dijital çağın getirdiği teknolojik bağımlılık filmin temel eleştiri alanlarını oluşturmaktadır. Çay’ın birleștirici özelliğinin ön plana çıkartılması ve insanların birbirlerine karşı diyalog geliștirmede bir simge olarak kullanılması söz konusudur (https://www.youtube.com/watch?v=qtn8Tyltna8).

\subsection{Görüntü Düzleminin Çözümlenmesi}

Görüntü düzleminde özellikle dostluk, gençlik ve aile teması ağırlıklı olarak ön plana çlkmaktadır. Gençler filmin ilk bölümünde duyarsız, ilgisiz ve mutsuz karakterler olarak betimlenirken, filmin ikinci bölümünde sıcakkanlı, mutlu ve ilgili karakterler olarak betimlenmiştir. 


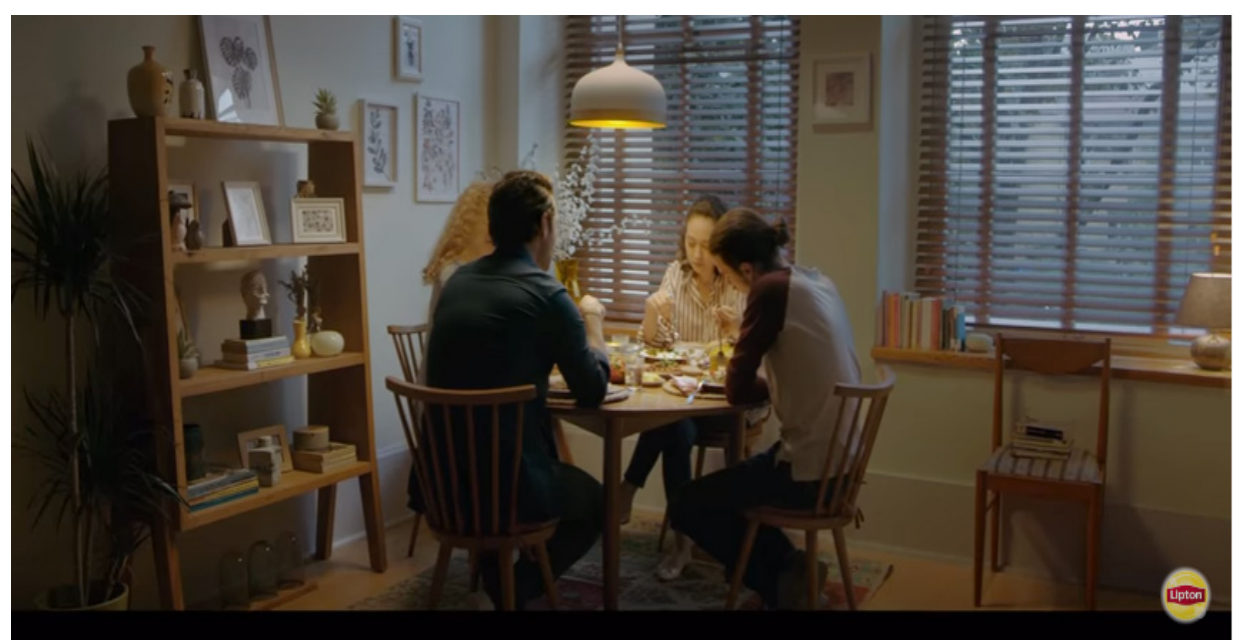

Görsel 1: Masada yemek yiyen aile

Filmin ilk planında iki erkek iki kadın karakter ev ortamında bir masada yemek yemektedirler(Görsel 1). Yemekte herkes dalgındır ve tabaklarıyla oynamaktadırlar. Hiç kimse birbiriyle konuşmamaktadır.

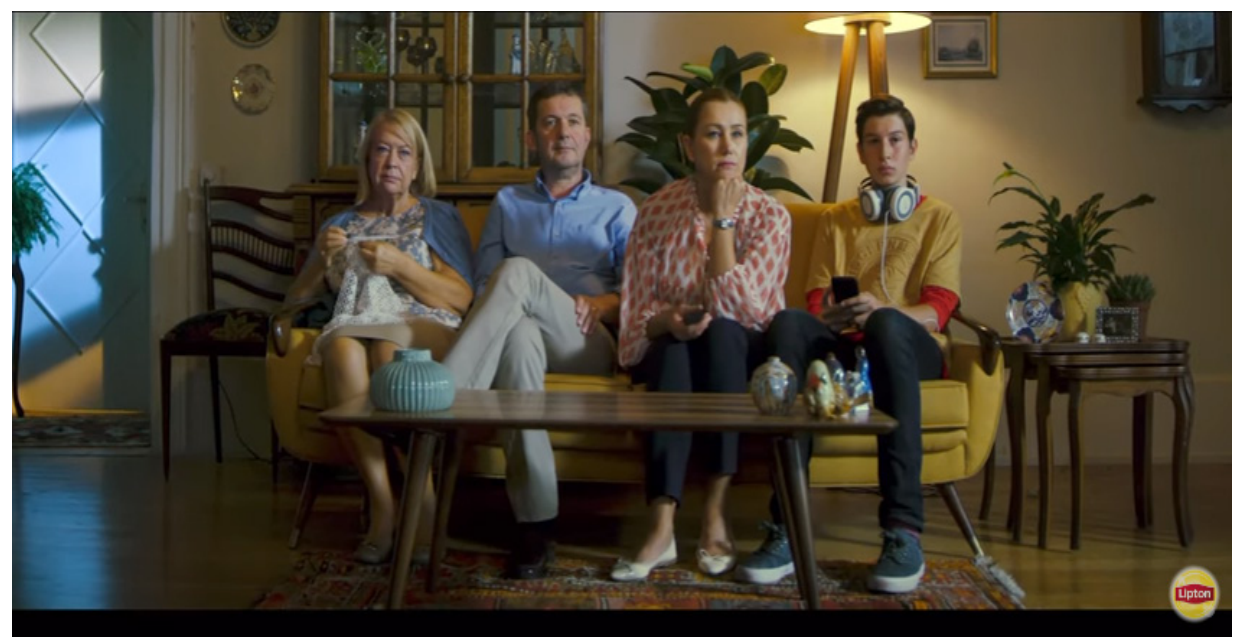

Görsel 2: Televizyon izleyen aile

Filmin ikinci planında ise çekirdek Türk ailesi resmedilmektedir (Görsel 2). Anneanne/Babaanne, anne, baba ve bir genç erkek çocuğundan oluşan aile televizyonun karşısında konumlandırılmış bir kanepede birlikte oturur vaziyette görülmektedirler. Anneanne/Babaanne elinde örgüsü varken ekranı takip etmektedir. Baba bacak bacak üzerine atmıştır. Anne elinde kumanda ile dikkatli bir şekilde ekrana bakarken, genç erkek çocuk boynunda kulaklıkla ve elinde cep telefonuyla ilgilenirken resmedilmişlerdir. 


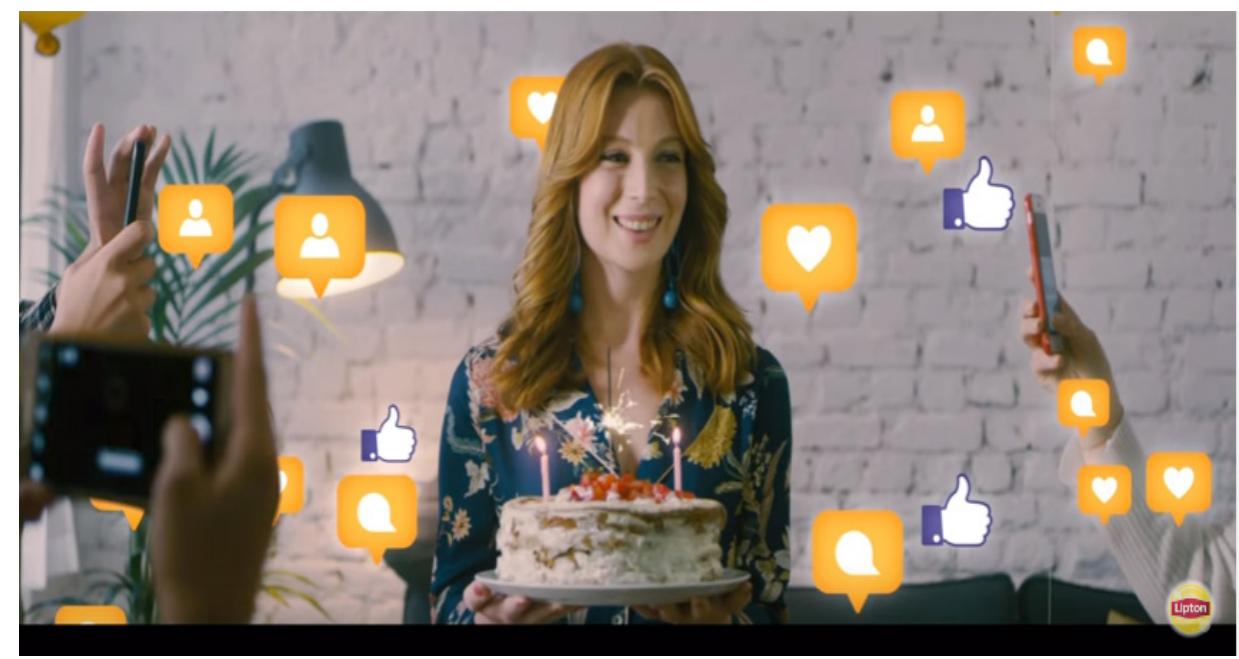

Görsel 3: Doğum gününü kutlayan kadın

Filmin üçüncü planı sosyal medya eleștirisi taşımaktadır. İş yerinde doğumgünü kutlayan bir kadın elinde pasta ile görülmektedir. Etrafında yer alan arkadaşları cep telefonları ile fotoğraf çekmeye başlarlar. Ekranda sosyal paylaşım sitelerinin beğeni ikonları görülmeye başlar. Genç kadın herkese poz vermektedir ve yakın planda çok mutlu olduğu görülmektedir (Görsel 3). Hemen devam eden planda ise asansörde bulunan insanlar gösterilmektedir. Asansördeki insanların hiçbiri birbiri ile konuşmamakta ve hiç kimse yokmuş gibi davranmaktadır. Film, yakın planda "Annemmm" yazan bir cep telefonu araması ile devam etmektedir. Genç kız annesinin aramasını sessize alarak telefonu yere koyarken betimlenmektedir. Hemen ardından hızlı bir kurgu ile mutfakta oturan bir çift görülür. Kadın dergi ile ilgilenirken erkek cep telefonu ile uğraşmaktadır. Ardı ardına dört farklı kapalı kapı hızlı bir şekilde gösterilir.

Film, dördüncü kapının açılmasıyla beraber ritim değiștirmektedir. Açılan kapının içinde bir genç kız ve iki erkek arkadaş ellerinde çay içerlerken sıcak bir sohbet gerçekleşmektedirler. Devam eden planda mutfak içerisinde anne ve baba ellerinde çay bardakları ile ayakta keyifli bir şekilde sohbet etmektedirler. Bir sonraki sahne deniz kenarında geçmektedir. Deniz kenarında üzgün bir şekilde oturan gencin yanına arkadaşı yaklaşır ve omzuna vurarak üzgün olan arkadaşının derdini paylaşırken elinde çay bardağı bulunmaktadır. Ardından kafede sohbet eden iki kadın arkadaş görülmektedir. Yoldan geçen samimi arkadaşlarını görürler ve masaya davet ederler. Üç kadın arkadaş masada çay ve kurabiyeler eşliğinde hasret giderirken resmedilmektedir. Bir sonraki sahne iki plandan oluşmaktadır. Berberde geçen ilk sahnede, tıraş olan müşteri yerinden kalmak istemektedir. Berber omzundan tutarak yerinde oturmasını ister. İkinci planda ise berber ve müşterinin ellerinde çay bardakları vardır ve samimi bir sohbet gerçekleşmektedir. Film hızlı bir kurgu ile ilerlemektedir. Spor bir arabanın şoför koltuğunda genç bir kadın ve ayakta genç bir erkek sohbet ederken görülmektedir. Arabanın üzerinde çay bardakları bulunmaktadır. Diğer planda ise mutfakta ellerinde çay bardaklarıyla kahkahalar atarak sohbet eden iki sevgili betimlenmiştir. Arkasından işyerinde mola veren iki iş arkadaşı ayakta çay içerken sohbet etmektedirler.

Film son planında aile vurgusunu tekrar yapmaktadır. Filmin ilk sahnesinde yer alan birbiriyle konuşmayan, ilgisiz aile bireyleri yerine; yemek masasında çay içip tatlı yerken kahkahalar atarak birbirleriyle sohbet eden aile bireyleri gösterilmektedir. 
Devam eden planda aile arka planda flu olarak kalırken ocakta kaynayan demlik ve çaydanlık görüntüsü ön plana çıkartılmaktadır. Mutfak masasında çay şekerliği ve Lipton demlik poşet çay kutusu dikkat çekmektedir. Ekrana "Çaylar Hazırsa \#Konuşalımartık" yazısı ve Lipton logosu girer. Son olarak bu görüntü de fluya düşer ve Lipton logosu ve sloganı "Hayatı Fark Et" ifadesi belirir ve film sona erer.

\subsection{Dilsel İleti Düzleminin Çözümlenmesi}

Reklam filminde karakterlerin konuşmaları duyulmamaktadır. Tamamen dış ses anlatıcı olarak görüntüler üzerine konuşmaktadır. Bu yönüyle reklam dili süsten uzak, sade ve öz bir bağlamda kurgulanmıştır. Dilsel mesajın bu şekilde kullanılması mesajın hedef kitleye istenilen şekilde ulaşması adına önem arz etmektedir. Mesajın mümkün olan en kısa sürede aktarılması ve izleyici tarafından algılanması reklamın dilbilimsel açıdan en belirleyici fonksiyonudur. Reklam iletisinin yoğunluğu ve dil düzeyinin izleyicinin dil düzeyi ile eşdeğerliği reklamın etkisini artırmaktadır (Küçükerdoğan, 2005, 38-39). Bu bağlamda, filmde seslendirilen metinler görüntülerle anlam bütünlüğü sağlayacak şekilde kurgulanmıştır. Filmin ilk sahnesi durgun bir müzikle başlar ve masada birbirleri ile ilgilenmeyen aile bireylerinin yer aldığı görüntünün üzerine dış ses "Konuşmamız gereken bir konu var. Aslında çok konu var" seslendirmesini yapar. Devam eden planda evde televizyon izleyen aile görüntüsü üzerine "Televizyona dönük koltuklar" ifadesi duyulmaktadır. Sirasıyla; iş yerinde doğum gününü kutlayan kadın görüntüsü üzerine "Birbirimizden önce sarıldığımız telefonlar", asansörde birbirleriyle ilgilenmeyen insan görüntüleri üzerine "Yüzyüze bakılmayan asansörler", annesinin araması reddeden genç kızın görüntüsü üzerine "Dönülmeyen cevapsızlar" ve mutfakta birbirleriyle ilgilenmeden oturup dergi okuyan ve cep telefonunu karıştıran karı-koca görüntüsü üzerine "İsmini bilmediğimiz komşular" ifadeleri duyulmaktadır.

Film ardı ardına farklı dört kapalı kapı görüntüsü ile bağlam değiștirmektedir. Dördüncü kapı görüntüsü ile müzik değişmekte ve hareketli bir hale dönüşmektedir. Dördüncü kapının açıldığı planda Lipton çaylarını içerken sohbet eden üç arkadaş görüntüsü üzerine "Peki konuşacak güzel şeylerimiz yok mu?" sorusu ile devam etmektedir. Hızlı bir kurgu ile sırasıyla; mutfakta çay içerken ayaküstü sohbet eden karı-koca görüntüsü üzerine "Eee bugün işte ne yaptınlar", parkta arkadaşına çay getirip dertleşen gençlerin görüntüsü üzerine" Canın neye sıkıldılar”, kafede sohbet eden üç kadın arkadaşın görüntüsü üzerine "Ne çok oldu görüşmeyeliler", berberde tıraş olan vatandaş ve berberin çay içme görüntüleri üzerine "Otur bir çay içelim sonra kalkarsınlar", Arabanın üzerine çay bardaklarını koyup sohbet eden arkadaş ve kafede oturan çiftin görüntüleri üzerine "Eee daha dahalar" ifadeleri seslendirilmektedir.

İş yerinde ayakta sohbet eden iş arkadaşlarının görüntüsünün ekrana girdiği anda müzik birden kesilir ve "Şimdi televizyon susacak" çağrısı duyulur. Ardından son plan olan masada kalabalık bir şekilde çay içerken keyifli bir sohbet gerçekleştiren aile görüntüsü üzerine "Biz konuşalım diye yayına kısa bir ara. Haydi çaylar hazırsa konuşalım artık" ifadeleri duyulmaktadır.

\subsection{Dijimodern Teknoloji ve Yalnızlık Göstergelerinin Düzanlam/Yananlam Düzeyinde Çözümlenmesi}

Reklam filminde Türk aile yapısı, geleneksel değerler ve toplumsal ilişkiler genel gösteren/gösterilen unsurlar olarak dikkat çekmektedir. Film iki farklı düzlemin 
kurgulanmasıyla oluşturulmuştur. Birinci düzlem; görsel, işitsel ve anlam bağlamında karamsar, karanlık, durağan, sıkıcı ve sıradan olan negatif değerler üzerine inşa edilmiştir. Birinci ve ikinci planda dikkat çeken en önemli gösteren sarı ışık veren abajur ve avizeler olarak dikkat çekmektedir. Film incelendiğinde kapalı mekanlarda gerçekleşen tüm planlarda abajur ya da avize aracılığı ile sarı ışık kullanıldığı görülmektedir. Turuncu, sarı, kırmızı gibi renkler daha net ve kolay anlaşılan dikkat çekici renklerdendir. Renkli görseller ile renksiz görsellerin farklı oranlarda aynı planda kullanılması reklam filminde karşıtlık unsurunu oluşturmaktadır. Bu șekilde yaratılan bir karşıtlık unsuru, tasarımda durağanlık oluşmasını engelleyen önemli yaklaşımlardan birisidir. Kimi zaman renkler kimi ürünleri veya markaları anımsatmaktadır(Küçükerdoğan, 2009, 24). Lipton logosu da sarı üzerine kırmızı harflerle oluşmaktadır. Ayrıca Lipton çaylarının bütün ambalajları da sarı renk üzerine oluşturulmuştur. Bu bağlamda reklam filminde gösterilen baskın renk olarak gösterilen sarı, markaya gönderme yapmaktadır. Birinci planda gösterilen ise ev ortamı ve içinde yaşanılan hayatlardır. Akşam yemek masasında oturan ve birbirleriyle ilgilenmeyen aile bireyleri, televizyon karşısına oturmuş anneanne/babaanne, anne, baba ve çocuk dijimodern yaşamın kuşatıcılığını simgelemektedir. Bu durum Baudrillard (2012)'ın medya kültürü eleştirisi yaparken televizyona yüklediği anlamla örtüşmektedir. Ona göre, ev içi alanda ayrılan konuma göre televizyon, dünyayı kolayca tüketilebilir toplumsal gerçeklik parçalarına çeviren derinliksiz, yapay bir ilişki sunmaktadır. Özellikle televizyon izlerken cep telefonunu kullanan ve boynunda kulaklığı asılı olan erkek çocuk imgesi; dijimodern yaşam pratiklerinin, toplum yaşamını ve mahrem ilişkileri nasıl derinden etkilediğini göstermektedir. Bu iki plan üzerine verilen "Konuşmamız gereken bir konu var. Aslında çok konu var. Televizyona dönük koltuklar...”ifadeleri gündelik yaşam alışkanlıklarının ve dijimodern teknoloji ağının bireyi kalabalıklar içinde yalnızlaştırdığına yönelik arka plan içermektedir.

Filmin üçüncü sahnesi doğrudan samimi ilişkileri öteleyen cep telefonu ve sosyal medya eleştirisi içermektedir. Sahnenin göstereni olarak elinde yaş pasta tutan genç bir kadın, etrafında cep telefonları ile fotoğraf çeken arkadaşları ve renkli balonlar bulunmaktadır. Gösterilen ise ev ortamında gerçekleşen bir doğum günü partisidir. Yakın plan çekimde doğum günü kutlanan kadın poz verirken, sosyal medya hesaplarındaki beğeni ve paylaşım ikonları ardı ardına grafik animasyon olarak ekrana gelmektedir. Bu esnada "Birbirimizden önce sarıldığımız telefonlar..." dış sesi duyulmaktadır. Göstergeyi oluşturan gösterilenin yan anlamları incelendiğinde; bireylerin gerçekte var olduğu dünyanın uzam ve süreminden bağımsız olarak hareket ettikleri vurgulanmaktadır. Farklı açılardan çekilen fotoğraflar, bunların paylaşıldığı sanal ortamlar, yapılan paylaşımlara yönelik gelen olumlu/olumsuz geri bildirimler ve bu sayede oluşturulan algı bireyi gerçek dünyadan koparmakta ve içinde bulunduğu kalabalıklar içinde yalnızlaştırmaktadır. Özellikle yakın çevresine yabancılaşan birey sosyal medya uygulamaları ile sanal bir toplumsallaşma yaşamakta ve yeni kimliğine bürünmektedir. Bu durum tam olarak da Kirby(2009)'nin ortaya koyduğu dijimodern çağda bireyin konumlandırılmasına yönelik eleştirilerin odak noktasını olușturmaktadır. Bu plan, geleneksel değerlere yönelik yabancılaşmayı da yan anlam olarak barındırmaktadır. Bayramlarda, doğum günlerinde ve kutlamaların olduğu özel anlarda büyüklere, yaşıtlara ve küçüklere sevgi ifadeleri samimi kodlarla verilirdi. Büyüklerin elleri öpülür, yaşıtların yanaklarından öpülür, küçüklerin ise yanakları öpülür ve başları okşanırdı. 
Günümüzde bu ifadeler sosyal medya içeriklerindeki imge ve görsel kodlarla yapılmaktadır. Dijimodern çağda sevgiyi gösterme ve hissettirme pratikleri içten, samimi ve yüzyüze olmaktan çıkıp yapay, derinliksiz ve dijital hale dönüşmüştür.

Filmin dördüncü sahnesi birbiri ardına çok hızlı kurguyla yapılan 3 farklı plandan oluşmaktadır. Her üç plan da asansör içinde bekleyen insanları resmetmektedir. Sahnenin göstereni sıkılmış yüz ifadesi ile bekleyen insanlardır. Gösterilen ise asansörde yaşanılan sıkılmışlıktır. Erving Goffman (2018), bir bireyin diğerine, onun orada bulunduğunu ve kendisinin onu açıkça gördüğünü kabul ettiğini anlatmasına yeterli olacak derecede görsel dikkat göstermesi, fakat hemen ardından, karşısındakinin özel bir merak ya da tasarı hedefi oluşturmadığını ifade etmek üzere dikkatini ondan başka bir yöne çevirmesini "uygar kayıtsızlık" olarak tanımlamaktadır. Filmin asansör sahneleri yan anlam olarak tamamen bir uygar kayıtsızlık eleştirisi getirmektedir. "Yüzyüze bakılmayan asansörler" ile duyulan dış ses de bu etkiyi güçlendirmektedir.

Filmin devam eden sahnesinde göstereni "Annemmm" yazan bir aramanın olduğu cep telefonu ve evin merdivenlerinde oturan genç kız dikkat çekmektedir. $\mathrm{Bu}$ görüntünün üzerine dış ses "Dönülmeyen cevapsızlar" seslendirmesini yapmaktadır. Yan anlam olarak değerlendirildiğinde günümüz Z nesline bir eleştiri bulunmaktadır. Annesinin aramasını sessize alarak neden açmadığını bilmediğimiz genç kız, konuşmak yerine susmayı tercih etmektedir. Filmin "Konuşalım Artık" teması ile yapıldığını düşündüğümüzde genç kızın bu sessizliği ve annesinin konuşma isteğini sessize alması olumsuzlanmıştır. Film hızlı bir kurguyla ilerlemektedir. Hemen ardından göstereni bir erkek, bir kadın, mutfak, dergi ve cep telefonu olan sahne görülmektedir. Bu görüntülerin üzerine dış ses "İsmini bilmediğimiz komşular..." seslendirmesini yapmaktadır. Bu sahne yan anlam olarak gündelik yaşam pratikleri bağlamında bireyin yalnızlaşmasını ve yüzyüze iletişim kanallarını kapatmalarını eleştirmektedir. Göstereni dört farklı kapı olan birer saniyelik kareler, oda ve apartman gösterileni olarak verilmektedir. Dördüncü kapının açılması ile film ritim olarak görsel ve işitsel bağlamda biçim değiştirmektedir.

Dördüncü kapının açıldığı odanın göstereni bir genç erkek, iki genç kız, çay bardakları, kanepe olarak dikkat çekmektedir. Gösterilen ise ev ortamında sıcak ve samimi bir sohbet gerçekleştiren 3 arkadaştır. Sahne yan anlam olarak filmin ilk bölümünde yer alan ve televizyon eleştirisi içeren aile sahnesine gönderme yapmaktadır. $\mathrm{Bu}$ sahnede filmin başlarında tek bir kanepeye oturup gözünü ekrandan ayırmayan anneanne/babaanne, anne, baba ve çocuk yerine; yine tek bir kanepeye oturan, ancak televizyon izlemek yerine çok samimi bir sohbet gerçekleștiren gençlere yer verilmektedir. $\mathrm{Bu}$ sıcaklığı ve yüzyüze iletişimi sağlayan metafor olarak içi çay dolu bardaklar resmedilmiştir. Bu yaklaşım filmin "Konuşalım Artık" temasını da dolayımlayan bir gönderge olarak "çay"ı, dolaysıyla Lipton markasını öncelemektedir. Ayrıca, dış ses "Peki konuşacak güzel şeylerimiz yok mu?" sorusu ile geleneksel değerleri ön plana çıkartıp televizyon üzerinden teknoloji eleştirisini sürdürmektedir.

Bir erkek, bir kadın, çay bardakları, yanan avize ve biberon gösterenleri olan devam sahnesinde, akşam eve gelmiş anne ve baba figürlerinin mutfakta ayaküstü günün değerlendirmesini yapmaları gösterilen olarak sunulmaktadır. Dış ses "Eee bugün iş'te ne yaptınlar..." seslendirmesini yapmaktadır. Ellerinde çay bardakları ile 
yapılan bu sohbet, filmin ilk bölümünde aynı masada yemek yerken birbirlerine kayıtsız kalan aile bireyleri üzerinden gönderme yapmaktadır. Çay metaforu yine kaynaşmayı, sıcaklığı, sohbeti ve birlikteliği yan anlam olarak içermektedir. Filmin devam eden tüm planlarında ana gösteren çay bardağı olarak dikkat çekmektedir. Sırasıyla gösterilenler ise deniz kenarında sohbet edip dertleşen iki erkek arkadaş, kafede sohbet eden üç kadın arkadaş, berber dükkanında tıraş sonrası sohbet eden esnaf ve müşterisi, arabanın yanında eğlenceli bir sohbet gerçekleştiren iki genç arkadaş, kafede oturan iki sevgili, iş yerinde karşılıklı masada çalışıp işe ara veren ve ayakta sohbet eden iki arkadaş olarak sıralanmaktadır. Devam eden bu sahnelerin üzerine dış ses "Canın neye sıkıldılar, ne çok oldu görüşmeyeliler, otur bir çay içelim sonra kalkarsınlar, eee daha dahalar...” ifadelerini söylemektedir. Hızlı bir kurguyla arka arkaya gelen bu sahnelerin tamamı yan anlam olarak; kaybolan ya da kaybolmaya yüz tutmuş ve dijimodern çağda yerini teknolojik içeriklere bırakmış olan geleneksel değerlerin önemini vurgulamaktadır.

Filmin son sahnesinin göstereni yemek masası, üç kadın, üç erkek, abajur, çay bardakları ve kurabiye tabaklarıdır. Gösterilen ise evin yemek odasında çay ve kurabiye eşliğinde gerçekleştirilen sıcak bir sohbet ortamıdır. Bu plan, Giddens $(2008,39)$ 'ın, “Tüm toplumlarda yeme-içme aslında, toplumsal etkileşim ve törenlerin gerçekleştirilmesi için ortamlar yaratmaktadır" yaklaşımı ile örtüşmektedir. Türk toplumu içerisinde aile bireyleri nedeni ne olursa olsun bir araya geldiklerinde sıcak bir sohbetin tamamlayıcısı olarak "çay" içmeye başlarlar. Bu yönüyle çay samimiyeti ve içtenliği yan anlam olarak temsil etmektedir. Plan dikkatli bir şekilde incelendiğinde aile bireylerinin çay içtiği bardaklar Türk usulü "ince belli" çay bardaklarıdır. Güneș $(2012,239)$, ince belli çay bardaklarını tarif ederken "...ince belli bardak, çay içme zevkini her duyu için üst düzeye taşlyacak niteliklere sahiptir. Bardağın şeffaf ve ince camdan mamul olması, çayın rengini görmeye izin verirken aynı zamanda dem ve su oranını ayarlamaya izin verir. Bununla beraber çay kaşı̆̆ı ile şeker karıştırıldığında kaşığın ince bardağa çarpması ile çıkan ses çay sohbetlerinin değişmez bir parçasıdır..." ifadelerini kullanmaktadır. Film bu perspektifden değerlendirildiğinde doğrudan Türk aile yapısına ve kültürel değerlerine gönderme yapmaktadır. Ayrıca, son sahne incelendiğinde abajurda yanan ışığın beyaz olduğu dikkat çekicidir. Film boyunca iç ortam sahnelerinde kullanılan avize ya da abajur ışığı sarı olarak kullanılmıştır. Beyaz ışık daha parlak ve net bir aydınlatma sağlamıștır. $\mathrm{Bu}$ sayede yemek masasında oturan aile bireylerinin yüzlerindeki mutluluk detayları daha çok belirginleştirilmiştir. Dış ses "Şimdi televizyon susacak. Biz konuşalım diye yayına kısa bir ara. Haydi çaylar hazırsa konuşalım artık" seslendirmesini yapar. Bu ifadeler, doğrudan televizyon eleştirisi yapmaktadır. Televizyon göndergesi sesli olarak aile temasının üzerinde verilmektedir. Televizyon imgesi aynı zamanda dijimodern çağda bireyi yalnızlaştıran diğer yeni iletişim teknolojisi araçlara da çağrışım yapan yan anlamları içinde barındırmaktadır.

\section{Sonuç}

Teknolojiye bağlı değişim toplum yaşamını son 20 yıldır derinden etkilemektedir. Dijimodern çağın insanları toplumsal örgütlenmeleri ağlar üzerinden gerçekleştirmektedir. Kültürün, iktidarın, ideolojinin, üretimin ve tüketim alışkanlıklarının yeniden inşa edildiği süreç yeni bir teknolojik paradigma ortaya çıkarmıştır. Sanal ortamların multimedya araçlarıyla dayatıldığı dijimodern çağda; izleyiciler, dinleyiciler, okuyucular ve kullanıcılar atomize edilerek parçalanmıştır. 
$\mathrm{Bu}$ sosyal ve kültürel ayrışma insanların kendilerini ifade edebilecekleri yeni alanların; yani sanal cemaatlerin oluşmasına neden olmuştur. İnsanlar artık evlerinde, işyerlerinde, sosyal alanlarda bağlı bulundukları ağlar sayesinde dünya ile bağlantı kurmaktadırlar. Cep telefonları, tabletler, bilgisayarlar vb. cihazlar sayesinde medya içeriklerine ulaşmada zaman ve mekan kısıtı kalmamıştır. Alışverişini internetten yapan dijimodern insanlar, sosyal medya aracılığı ile bağlı bulundukları platformlarda yeni kimlikler ve algılar oluşturmaktadır. Tüm bu dijital kuşatılmışlık bireyleri geleneksel kültürel değerlerden uzaklaştırmış ve onları hazmetmiștir.

Reklam metinleri sadece tüketim alışkanlıklarının seyrini belirleyen sıradan çıktılar olarak değerlendirilmemelidir. Reklam metinleri dilsel ve görsel olmak üzere iki düzlemde kültürel ve ideolojik göndermeler de yapmaktadır. Ürünün kendisi kadar, onu gösteren göstergeler ve ortaya çıkan anlam/içerik reklam iletisinin göstergebilimsel olarak çözümlenmesinde önem taşıyan bileşenlerdir. Gösteren ile gösterilen arasındaki ilişki mitolojik, fantastik ya da gerçekdışı olabilmektedir. Reklamlar, anlam sistemleri arasında sürekli bir bilgi alışverişi gerçekleştirirler. Dolayısıyla toplum yaşamının farklı alanlarına ait değerler, bireyler tarafından farklı yorumlar içererek algılanmaktadır.

Lipton "Konuşalım Artık" temalı reklam filmi; dijimodern insana, geleneksel ve insani değerleri hatırlatarak başını teknolojiden kaldırması gerektiğini söylemektedir. Reklam filmi, aile ilişkileri başta olmak üzere toplumsal iletişimin teknoloji odaklı olarak zayıfladığı vurgusu yapmaktadır. Filmin ilk bölümünde toplum; giderek cep telefonu, tablet ve televizyon bağımlısı olarak gösterilmektedir. Yüzyüze iletişim kurmaktan kaçınan, dertleşmeyen, selamlaşmayan ve gitgide yalnızlaşan birey, geleneksel değerlere de yabancılaşmıştır. Bu bağlamda, filmin ikinci bölümü çözüm önerisinde bulunmaktadır. Ardı ardına kapalı gösterilen farklı dört kapı metaforu insanların kendi iç dünyalarına gönderme yapmaktadır. Teknolojiye konulacak mesafenin, insan ilişkilerini daha sıcak ve içten yaşamalarına neden olacağı fikri "çay" imgesi üzerinden altı çizilerek vurgulanmaktadır.

Filmde "çay"ın sadece bir içecek olmadığı vurgulanmaktadır. Gündelik toplumsal faaliyetlerimizin bir parçası olarak "çay"ın simgesel bir anlamı vardır. Çay içmek için bir araya gelen insanlar genellikle ne içtiklerinden çok bir araya gelmek ve sosyalleşmekle ilgilenmektedirler. Çay, özellikle Türk kültürü içerisinde vazgeçilmez bir yere sahiptir. Lipton, "Konuşalım Artık" temasıyla çayın birleştirici özelliğini ön plana çıkartarak reklam filmini hazırlamıştır. Film, çayın içerik unsurlarından (demi, kokusu, rengi vb.) ziyade, davranışsal ve kültürel (içtenlik, samimiyet, dertleşme, hasret giderme vb.) unsurlarını ön plana çıkartmıştır. Bunu yaparken de Türk insanının yaşam pratiklerinden kesitler üzerine bir senaryo oluşturmuştur. Dijimodern insanın unuttuğu, hatta $\mathrm{Z}$ neslinin yabancılaştığı karşılıklı yüzyüze iletişim özlemi, "çay"ın sıcaklığı ve birleştirici simgesel öğeleriyle izleyicilere sunulmuştur. Lipton'un duygulara seslendiği bu reklam filmini kurumsal marka imajını güçlendiren sosyal bir girişim olarak değerlendirmek mümkündür.

Lipton "Konuşalım Artık" temalı reklam filmi dijimodern birey eleştirisi yaparken multimedya iletişim araçlarını ve dijital sosyal ağları ön plana çıkarmaktadır. Ancak filmin sonunda ekrana "\#Konuşalımartık" başlıklı bir hashtag yansıtmaktadır. Yüzyüze iletişimin azalması ve geleneksel değerlerin sosyal ağlar aracılığı ile yok 
olmasını eleştiren bir film, sonuç itibariyle izleyicileri tekrar bir sosyal paylaşıma davet etmektedir. Bu yönüyle film vermek istediği mesaj ile ironik bir şekilde çelişmekte ve yalnızlaşan birey eleştirisinin tartışmasını sosyal ağlarda dolaşan dijimodern toplum üyelerine bırakmaktadır.

\section{Kaynakça}

Ayhan, B. ve Çavuş, S. (2014). İzleyici Araştırmalarında Değişim: Kullanım ve Doyumlardan Bağımlılığa, Selçuk İletişim Dergisi, Cilt 8, Sayı 2, 32-60.

Babacan, M. E. (2015). Sosyal Medya ve Gençlik, Açılım Kitap, İstanbul.

Barthes, R. (1979). Göstergebilim İlkeleri, Berke Vardar ve Mehmet Rifat (çev), Kültür Bakanlığı Yayınları, Ankara.

Barthes, R. (2005). Göstergebilimsel Serüven, Mehmet Rifat ve Sema Rifat (çev), Yapı Kredi Yayınları, İstanbul.

Baudrillard, J. (2012). Tüketim Toplumu, Ayrıntı Yayınları, İstanbul.

Burton, G. (1995). Görünenden Fazlası, Nefin Dinç (çev), Alan Yayıncılık, İstanbul.

Fiske, J. (2015). İletişim Çalışmalarına Giriș, Süleyman İrvan (çev), Pharmakon Yayınevi, Ankara.

Giddens, A. (2008). Sosyoloji, Kırmızı Yayınları, İstanbul.

Goffman, E. (2018). Toplum İçinde Davranmak, Adem Bölükbaşı (çev), Heretik Yayınları, Ankara.

Güneş, S. (2012). Türk Çay Kültürü ve Ürünleri, Milli Folklor Uluslararası Kültür Araștırmaları Dergisi, Yıl:24, Sayı:93, 234-251.

Holt, D. B. (1997). Poststructuralist Lifestyle Analysis: Conceptualizing The Social Pattering of Consumption in Postmodernity, Journal of Consumer Research, 23 (4), 326-350.

Kellner, D. (2010). Medya Gösterisi, Zeynep Paşalı (çev), Açılım Kitap, İstanbul.

Kıran, A. ve Kıran, Z. (2003). Yazınsal Okuma Süreçleri, Seçkin Yayıncılık, Ankara.

Kirby, A. (2009). Digimodernism: How New Technologies Dismantle the Postmodern and Reconfigure Our Culture. London: TheContinuum International Publishing Group.

Küçükerdoğan, R. (2005). Reklam Söylemi, Es Yayınları, İstanbul.

Küçükerdoğan, R. (2009). Reklamda Kültürlerarasılık: Reklam İletişiminde YerelKüresel Göstergeler, Es Yayınları, İstanbul.

Küçükerdoğan, R. (2011). Reklam Nasıl Çözümlenir?, Beta Basım Yayım, İstanbul.

Lyotard, J. F. (1994). Postmodern Durum, Ahmet Çiğdem (çev), Vadi Yayınları, Ankara.

McLuhan, M. (1964). Understanding Media: The Extensions of Man, NY, USA: New American Library.

Möngü, B. (2013). Postmodernizm ve Postmodern Kimlik Arayışı, Atatürk Üniversitesi Sosyal Bilimler Enstitüsü Dergisi, 17 (2), 27- 36.

Odabaşı, Y. (2012). Postmodern Pazarlama, Mediacat Kitapları, İstanbul. 
Palfrey U. ve Gasser, J. (2017). Doğuştan Dijital, Nagihan Aydın (çev), İstanbul Kültür Üniversitesi (İKÜ) Yayınevi, İstanbul.

Prensky, M. (2001). Digital Natives, Digital Immigrants, On theHorizon MCB UniversityPress, 9 (5), 1-6.

Proctor, T. ve Kitchen, P. (2002). Communication in Postmodern Integrated Marketing, Corporate Communications: An International Journal, Vol.7, 3, 144-154.

Robins, K. (1999). İmaj, Nurçay Türkoğlu (çev), Ayrıntı Yayınları, İstanbul.

Taş H. Y., Demirdöğmez M. ve Küçükoğlu M. (2017). Geleceğimiz Olan Z Kuşağının Çalışma Hayatına Muhtemel Etkileri, OPUS-Uluslararası Toplum Araştırmaları Dergisi, Sayı (7)13, 1031-1048.

Tellan, D. (2009). Reklam Etkilerini ve Reklamın Etkinliğini Ölçmek: Modeller ve Teknikler, Derya Tellan (der), Reklamcllı: Bakmak ve Görmek, Ütopya Yayınevi, Ankara.

Torlak, Ö. ve Ay, U. (2014). Facebook'ta Bulunma Amacı ve Facebook Reklamlarına Duyulan İlgi Arasındaki İlişki, Anadolu Üniversitesi Sosyal Bilimler Dergisi, 14(4), 83-94.

Ünal, S. (2014). Göstergebilimsel Açıdan Sembolik Tüketim, Detay Yayıncılık, Ankara.

Vermeulen, T \& Akker, R. V. D. (2010). Notes on Metamodernism. Journal of Aesthetics \& Culture, 2(1), 1-14.

Williamson, J. (2001). Reklamların Dili Reklamlarda Anlam ve İdeoloji, Ahmet Fethi (çev), Ütopya Yayınevi, Ankara.

Whiting, A. ve Williams, D. (2013). Why people use social media: a uses and gratifications approach, Qualitative Market Research: An International Journal, 16(4), 362-369.

Yıldırım, A. ve Şimşek, H. (2008). Sosyal Bilimlerde Nitel Araştırma Yöntemleri, Seçkin Yayıncılık, Ankara.

İnternet Kaynakları

https://www.youtube.com/watch?v=qtn8Tyltna8 Erişim: 20 Mart 2019.

https://www.youtube.com/watch?v=X51qzrJ60Gc Erişim: 16 Mayıs 2019.

https://www.youtube.com/watch?v=RiUNAjaeAFc Erişim: 20 Mayıs 2019. 
